\title{
Multiple Determinants of Milk Production in Africa: The Example of the Diversity of Dairy Farming Systems in the Mbarara Area (Uganda)
}

\author{
Véronique Alary,* Julien Chalimbaud ** \\ $\&$ Bernard Faye ***
}

\begin{abstract}
In developing countries, animal products supply presents a major challenge in meeting the demand for the two next decades. Many researchers point out the necessity for a 'reasoned intensification', especially in agricultural areas, by integrating agriculture and livestock activities. But intensification only occurs on specific farms. How can one explain the different dairy developments or technical options between farms? An analysis of the diversity of dairy farming systems in Mbarara district (Uganda) has been conducted from a monthly crosssectional survey of a sample of 22 farmers, identified from a large household survey (183 dairy producers). The multi-table factorial analysis allows a thorough review of the interactions and points out some causal relationships between the development of the dairy systems and the social and technical management of the whole farm. This analysis underlines the key factors of intensification such as genetic improvement or market opportunities; but also the degree of intensification which is well correlated to the stage of family development. If the
\end{abstract}

* CIRAD-ES (Centre de coopération Internationale en Recherche Agronomique pour le Développement), Département Environments and Societies, TA C-18/A, Campus de Baillarguet, 34398 Montpellier cedex 5, France.

** French-Uganda Mbarara Milk Project, Mbarara, Uganda.

*** CIRAD-ES, UR Systèmes d'élevage, TA C-18/A, Campus de Baillarguet, 34398 Montpellier cedex 5, France. 
livestock may reinforce different functions (security, consumption, cash flow) according to the farm type, the results show that all these functions exist for all the farm types, either in the pastoral or agricultural areas. So these results question the stereotypes built on the different livestock systems in Africa.

\section{Résumé}

Dans les pays en développement, l'approvisionnement en produits d'origine animale présente un défi majeur à relever pour faire face à la demande au cours des deux prochaines décennies. Bon nombre de chercheurs font remarquer la nécessité d'une « intensification raisonée », en particulier dans les régions agricoles, en intégrant à l'agriculture les activités d'élevage. Cependant, l'intensification n'est pratiquée que dans des exploitations spécifiques. Comment peut-on expliquer l'inégal développement dans la production laitière ou bien les différences de choix techniques entre les exploitations ? Une analyse de la diversité des systèmes de production laitière dans la région de Mbarara (Ouganda) a été faite sur la base d'une enquête mensuelle représentative portant sur un échantillon de 22 exploitations identifiées lors d'une enquête/ménage (183 exploitations). L'analyse factorielle de plusieurs tableaux permet de faire une étude compléte des interactions et indique quelques relations des cause à effet entre le développement des systèmes de production laitière et la gestion sociale et technique de la ferme dans son ensemble. L'analyse met en relief les facteurs clés de l'intensification tels que l'amélioration génétique ou les opportunités offertes par le marché, mais également le degré d’intensification qui est étroitement lié au niveau de développement de la famille. Si le bétail peut renforcer différentes fonctions (sécurité, consommation, trésorerie) selon le type d'exploitation, les résultats montrent que toutes ces fonctions sont présentes dans tous les types d'exploitations des zones pastorales comme des zones agricoles. Par conséquent, ces résultats remettent en question les clichés que l’on se fait sur les différents types d’élevage en Afrique.

\section{Introduction}

For a long time, in Africa, milk activity at the farm and the household level has been confined to a way of diversification or intensification in mixed farming systems or looked upon as the main social component of traditional pastoral systems. Today the risk is in restricting milk production development to poverty reduction on small-scale farms. Few research studies consider milk production as a component of the whole strategy of the farm, including social or societal, economic, agronomy and institutional aspects. We propose to use the conceptual approach of 'farming system' to break down the process of milk development at the farm level and to identify the rationality that underlies the different milk strategies beyond the social and geographical determinants. 
The present study has been conducted in the Mbarara district in the south west of Uganda which provides, with four others districts, more than onethird of the national milk production. Besides the disengagement of the Ugandan government in agricultural financing, an important dynamic of the private sector around dairy activity is quickly developing, including matters such as transport and distribution, with the creation of five new dairy plants since the mid-1990s. However, the rapid development of intensive and productive dairy activities around Kampala and the low level of milk consumption by inhabitants at the national level, ${ }^{1}$ constitute both a threat to the viability of dairy systems in Mbarara and an encouragement to production. The development of dairy production is strongly encouraged by the Ugandan government $^{2}$ as a means to increase rural income. Increasing returns, poverty and malnutrition alleviation are the main expectations of this dynamic in a more and more competitive sector.

One first survey of about 183 dairy producers distributed in three agroclimatic zones in Mbarara district differentiated heterogeneous systems of breeding (Grimaud et al., 2004). Between the traditional extensive pastoral systems of dry areas in Nyabushozi county, and the intensive and marketoriented systems of the agro-pastoral county of Kashari, near Mbarara, we can observe a variety of more or less complex systems in which milk may be either a way of investment of the agricultural surplus from the cropping system or a way to diversify the sources of income. Sometimes it is difficult to appreciate the importance of each factor in making the decision to produce and sell milk: what are the various logics which explain the differentiated milk developments at the farm level? Might livestock saving be a safety strategy for which all farmers search? Are the determinants of milk production only confined to market opportunities? How can we explain different degrees of intensification in one very particular zone?

\section{Brief overview of the literature}

The determinants of milk production in African livestock systems have been widely described for pastoral systems. In such research work, milk is considered as a social product more than an economic or lucrative concern (Corniaux 2005). In this way, the dairy activity is one component of the pattern of life in which animals embody key cultural and social roles (Van Ecbert et al., 1989; Moll and Dietvorst 1999). In these pastoral systems, the meat consumption or sale concerns only old and unproductive animals and the animal sale intervenes only in the cases of extreme social needs (Boutonnet 2000). Therefore, pastoralists manage their breeding systems and livestock investments so that the milk production covers family and social needs. 
Besides, in agro-pastoral systems, small ruminants are often considered as a cash box, and large ruminants, especially dairy cows, as a live saving for agricultural farmers. In this way, animals constitute a capital which may be used to fund some social or agricultural investment or cover urgent social needs (Slingerland 2000; Bosman and Moll 1997). Animals constitute a live saving in the sense that producers invest agricultural income surplus in livestock. Through the by-products (milk, calves), this capital provides more safety and available interest than bank savings which may be unreliable and sometimes even experience fraudulent bankruptcy. For Slingerland (2000), animals are 'risk safe investment'; they are resistant to situations of shock. With animals, producers can thus face up to urgent social needs.

For dairy market-oriented farmers, livestock represents both a live saving and productive capital (such as the land) from which they extract their own consumption and cash products. In the two cases, milk would be the capital profit. But self-consumed milk always contributes an equivalent protein that is difficult to estimate in a low protein ration. Moreover it is difficult to estimate the real benefit in terms of family employment or social effects, such as milk donations in traditional society. When milk production becomes more regular with marketing opportunities, it provides a daily cash flow even in unproductive agricultural seasons or dry weather, and animals provide a means of 'banking' resources (Starr 1987).

Finally, there are the modern dairy farmers who attempt to increase milk production by way of genetic improvements, auto-selection of more productive cows, increasing feed resources (fodder crops implanting, pastoral and water management), material investment to improve milk quality (pickup transport, metal churns). Milk becomes the main activity and livestock a productive capital, although it always remains a live saving to cover technical or social urgent needs.

The passage from a social and self-consumed product to a lucrative and economic activity is often attributed to the development of a network of dairy collections, in comparison with the dairy development in developed countries (Vatin 1996). But it is easy to observe different individual milk strategies in one locality covered by the same facilities in terms of infrastructure in milk collection.

The scientific literature and expert reports have mainly focused the analysis of the development of milk activity on the traditional functions attributed to the animals as a live capital: investment, saving, or monetary surplus for the different farming systems. But do these key functions of milk attributed to each farm type not conceal a more complex reality? Do not all farmers seek security with the live saving? Are the investment logics in genetic improvement or milk marketing (churns, transport, etc.), only linked to market opportunities? 
The contextual literature gives much qualitative description of the livestock systems and the different functions attributed to milk, notably in term of poverty reduction. But few researchers attempt to formalise and quantify these functions by way of observation and surveys.

How farmers approach decision-making needs help us to identify and analyse the type and the nature of linkages between the dairy strategies and the global socioeconomic structure and management of the farm and the household. The main difficulty is that milk activity is completely integrated in the overall dynamic of the farm development. The driving forces of its development are a function of both the internal decision-making by farmers, and external factors such as infrastructure, milk demand, etc. We propose to identify each function with a set of variables that will enable us to undertake a multi-table factorial analysis.

\section{Material and methods}

\section{Sampling of the farmers}

A previous study performed in 1998 with 183 farmers in three counties made it possible to identify, after clustering, four large groups of breeders who are differentiated in terms of their agricultural diversification, herd structure and breeding (Dabusti and Vancauteren 1999; Chalimbaud et al., 2001; Faye 2000). The authors distinguished four main groups (G1) the 'Pastoralists' or the extensive systems of breeding in the pastoral area of Nyabushozi, based on animal sale and milk consumption; (G2) The 'mixed farming systems' in the agricultural area of Ibanda (mainly a coffee zone) which invest agricultural surplus in livestock; (G3) the 'agro-pastoralists' or agro-pastoral systems located in the county of Kashari, who are improving milk performance through genetic and pastoral management; and finally (G4), the 'modern farmers' or the intensive systems specialising in dairy activity.

To understand the specific logics of investment in milk production and the role of milk in generating income and improving rural livelihoods, a monthly cross-sectional survey of 22 breeders chosen in the four identified groups was undertaken from June 1999 to May 2000. This survey registered, on a monthly basis, animal performances (birth/mortality, disease, calving weight, lactation curve, etc.), breeding management (mainly feeding management), and economic decisions such as investment, expenditure and exchanges (animal sale and purchase, real prices, animal charges, milk receipt). One supplementary survey focused on the approach of the whole farming system, including the assessment of the importance of the other agricultural activities and off-farm activities. 


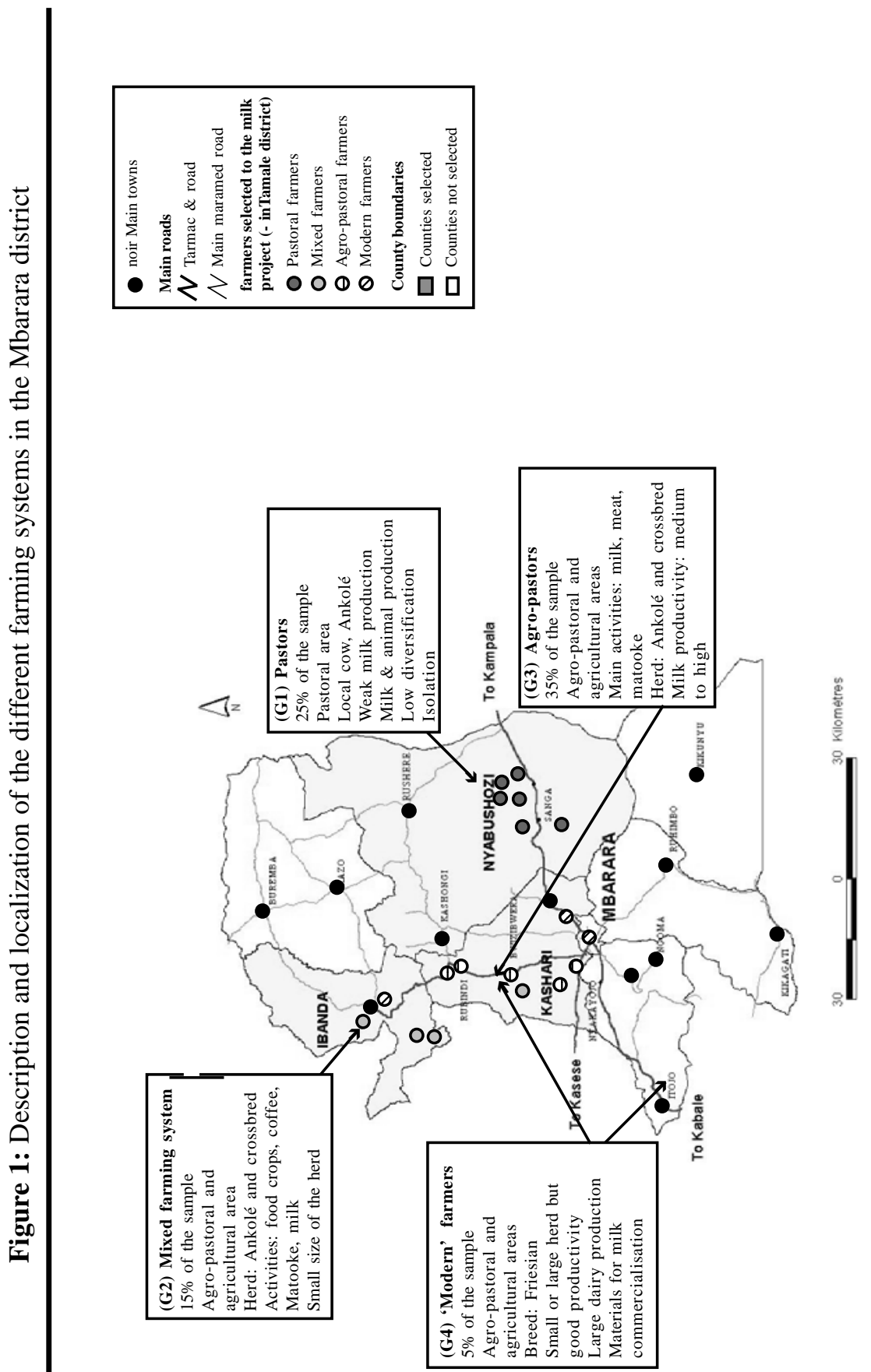




\section{Strategic and economical indicators}

Measuring the social and economic importance of milk activity at the farm level makes it possible to estimate the functions of saving and of investment and their relative weight in the productive logics of farmers. To distinguish between these two functions (live saving or investment), different indicators are used. The rate of numeric yield (number of calves per cow) is usually used as an indicator of live saving, and the demographic and genetic composition of the herd is an indicator of investment decisions around milk production. But the demographic composition of the herd reflects as much the saving logics of such farming as it does the investment decision. The sale of the surplus of milk could be also considered as the interest on saving, and would be consistent with a saving logic. In contrast, self-consumption decisions reflect economic decisions (nutritive intake of the family work force), as well as cultural decisions (satisfaction of custom) or social decisions (the exchange or offer of milk calabashes).

The degree of milk specialisation and intensification is estimated by the rate of milking cows in the herd, the milk productivity, and the level of capital investment per Tropical Livestock Unit (TLU). The logics of specialisation and intensification or the logics of live saving and investment are in keeping with farming strategies and household objectives. This implies the need to identify links (or absence of links) among these logics represented by the herd structure, the livestock system and the milk strategies in themes 3,4 and 5 , and the pattern of living (theme 1 ) or the degree of diversification (theme 2) (Table 1).

One supposes that the strategic choices of farmers in matters of intensification and specialisation are strongly linked to the demographic composition of the household (notably the ratio of consumer numbers and active members). But they also involve the individual characteristics of the head of the household, such as his social origin, which defines or orients social, cultural and economic rules. This does not mean that intensification will be confined to only one community or only one type of head of household. But the modes of intensification or specialisation might vary with family or community factors.

Besides, the degree of diversification in agricultural activities or in offfarm activities has generally been considered as one strategy or attitude towards risk aversion in the literature. This degree of diversification is demonstrated in particular in very vulnerable areas (hard climatic conditions, decline of ground fertility) or in dynamic areas where important commercial activities are developing alongside urban demand (Reardon et al., 1992). But the level of diversification varies also with the competence and the availability of family workers, the social and economic expectations or needs at the house- 
hold level, and the local opportunities (Tchayanov 1924). This explains the choices of two themes: theme 1 on the pattern of living and theme 2 on the degree of diversification.

Table 1: The set of variables representing each theme at the farm level

\begin{tabular}{|c|c|}
\hline Theme & Variables \\
\hline $\begin{array}{l}\text { Theme 1: Pattern } \\
\text { of living }\end{array}$ & $\begin{array}{l}\text { Characteristics of the head of family (age, scholar level) } \\
\text { Family members (schooled children, number of } \\
\text { dependants) } \\
\text { Environment (isolation, distance to milk collect } \\
\text { centre or market, non-agricultural activity) }\end{array}$ \\
\hline $\begin{array}{l}\text { Theme 2: } \\
\text { Diversification }\end{array}$ & $\begin{array}{l}\text { Cropping system (part of food crop, cash crop like coffee } \\
\text { or matooke); } \\
\text { Other breeding activities in 99/00 (small ruminants); } \\
\text { Family and salaried workers on the cropping system }\end{array}$ \\
\hline $\begin{array}{l}\text { Theme 3: } \\
\text { Herd structure }\end{array}$ & $\begin{array}{l}\text { Number of cows, males, young males, heifers and veal per } \\
\text { race; Genetic composition of the herd; Milk TLU / Total } \\
\text { TLU; }\end{array}$ \\
\hline $\begin{array}{l}\text { Theme 4: } \\
\text { Livestock } \\
\text { management }\end{array}$ & $\begin{array}{l}\text { Animal sale and purchase; Charges per TLU (salaries, } \\
\text { transhumance tax, veterinary fees, rent charges, cost of } \\
\text { production of fodder crops, maintenance, water charges); } \\
\text { Family and salaried workers implied in breeding } \\
\text { management; Private pastoral area/ Total area }\end{array}$ \\
\hline $\begin{array}{l}\text { Theme 5: Milk } \\
\text { strategies (inten- } \\
\text { sification, specia- } \\
\text { lisation, marketing) }\end{array}$ & $\begin{array}{l}\text { Seasonal daily milk yield; milking cow/ productive animal; } \\
\text { Material investment; average sale price; } \\
\text { Destination of milk; self-consumed part per capita. }\end{array}$ \\
\hline
\end{tabular}

\section{Statistical analysis}

The multiple factorial analyses constitute interesting statistical tools to analyse the dependencies or causal effects between groups of variables that reflect one aspect or one profile of the whole farm system (Faye et al., 1990). This method allowed us to analyse the complementarities (or not) between the different functions for each milk strategy farm type. The advantage of this method is that one can attribute the same weight to each group of variables. The different steps of the analysis are described in Figure 2. 
Figure 2: Description of the methodological step

Step 1: Survey of 183 farmers in three counties in the Mbarara district

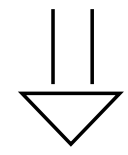

Step 2: Monthly cross sectional survey of 22 farmers who represent the main farming systems in the studied area

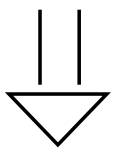

Step 3: Separated multi-factorial analysis on the different themes: 1) pattern of living; 2) degree of diversification; 3) Herd structure; 4) Livestock management, 5) Milk strategies.

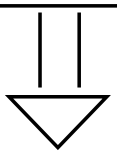

Step 4: Crossed analysis of the different sub-systems of the farm (themes 1 to 4 ) with the milk strategies (theme 5)

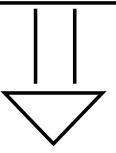

Step 5: Reconstruction of the milk strategies by the projection of the clusters resulted from the dairy strategies variables on the factorial plan resulted from a multi table factorial analysis conducted on the theme 1,2,3 and 4 (table 1) (Escofier \& Pagès 1983, 1984). 


\section{Results}

\section{Decomposition and reconstruction of dairy strategies}

The separate statistical analysis of each group of variables relating to one theme (see table 1) reveals original profiles of the population for each theme. From this analysis, it was possible to determine new sub-groups that gathered farmers who belonged to different communities or socio-agro-climatic areas. Table 2 presents briefly the different sub-groups resulting from a separated factorial analysis on each theme (col. 1, table 2). Four main variables allow the differentiation of the pattern of living: the degree of isolation (geographic location), the age and schooling of the head of the household, and the number of dependent persons in the family. Three modes of diversification are identified: the matooke, the staple food in association with coffee or small ruminants. Four modes of livestock management are identified: (i) herding in cowsheds; (ii) a feeding system with fodder crops, ${ }^{3}$ (iii) a grazing system with investment in water or pasture management, and (iv) extensive grazing systems. The last theme, herd structure, classified farms according to the degree of genetic improvement. Five sub-groups were identified: (i) the 'Ankolé, local cow' sub-group that included mainly the pastoralists; (ii) the 'Unkown breed' sub-group that referred to farmers who make their first investment in livestock; (iii) the 'crossbred' sub-group consisting of farmers who have a mixed race herd, and (iv) the 'genetic improvement' subgroup where farmers attempt to invest in improved milk cows but may have difficulty in maintaining the dairy herd and (v) the 'Friesian dominance' subgroup referring to farmers who have invested in a high-yield dairy herd.

These different sub-groups are cross-tabulated with the main dairy strategy sub-groups presented in figure 3 . The first sub-group, 'extensive', represents the extensive systems in the pastoral area oriented to milk consumption. The sub-group 'surplus' represents the traditional systems in the pastoral or agropastoral areas in which a small part of the milk is sold. The 'saving' subgroup is composed of agricultural systems in which the farmers attempt their first investment of the agricultural surplus in livestock activity. The 'diversified' sub-group represents the mixed farming systems which make a profit out of dairy livestock. The 'intensive' sub-group refers to agro-pastoral systems in which farmers invest in pastoral management. Finally, there is the 'modern' sub-group where milk specialised systems exist. 


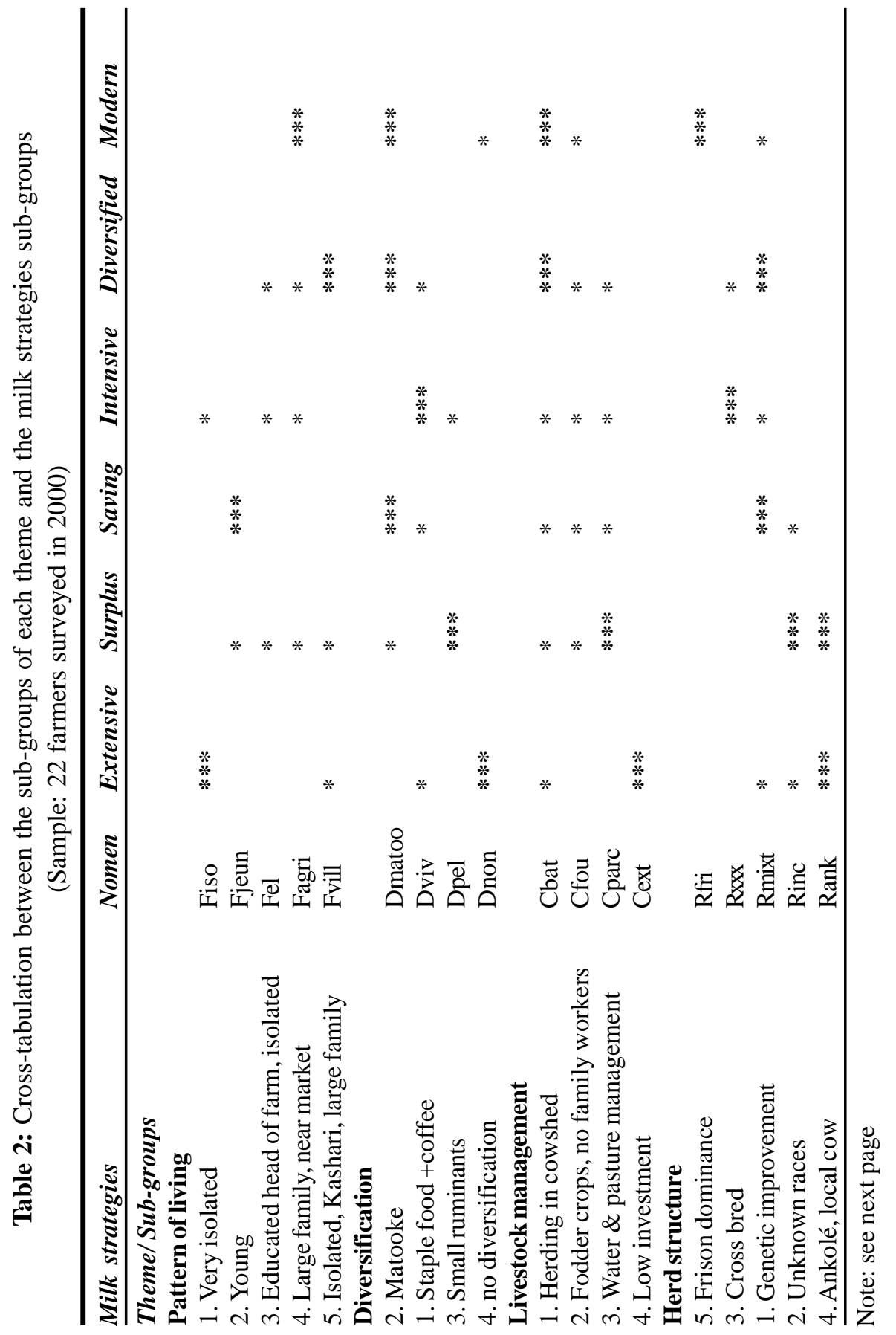




\section{Notes to Table 2}

1. Strategy milk sub-groups: 1. 'Extensive': Extensive systems in the pastoral area oriented to milk consumption; 2. 'Surplus': traditional systems in pastoral or agro-pastoral area in which a small part of milk is sale; 3. 'Small saver': agricultural systems with first investment in livestock; 4. 'Intensifying': agropastoral systems in which farmers invest in pastoral management; 4. 'Diversified': Mixed farming system; 6. 'Modern': Milk specialised systems.

2. Dark grey with three stars: for the theme, more than $50 \%$ of the farmers in the strategy milk sub-group belong to the sub-group of the theme; no star: for the theme, less than $50 \%$ of the farmers in the strategy milk sub-group belong to the sub-group of the theme; White with no star: for one theme, no farmers in the strategy milk sub-group belongs to the sub-group of the theme.

The results presented in table 2 show the degree of linkage between the strategy milk sub-groups and the others sub-groups. These results demonstrate significant relationships between the milk strategy sub-groups, and the degree of diversification and herd structure. This link is not found for the two other themes, pattern of living and livestock management, for which the farmers of some sub-groups of milk strategies are scattered in the different sub-groups of the two themes.

These results confirm other evidence, for example, the farmers who make the highest profit on dairy activity invest in the most productive animals, like Friesian cows. Farmers oriented to self-consumption maintain their local breeds. Further, the more remote farmers consume the majority of their milk production, unlike the farmers located near a market who sell a large part. But these results allow also one to challenge some common stereotypes.

First, there is only a small difference with regard to livestock management, especially concerning the housing and feeding systems. The farmers who keep animals in stalls ('Cbat') are listed on all the dairy strategy types. Vice versa, in each milk strategy sub-group, farmers practise different feeding systems. Only the 'extensive' and the 'modern' systems are quite well distinguished from the housing and feeding system. The 'extensive' systems practise mainly grazing for their herds, without cowsheds. At the opposite extreme, in the 'modern' system, the herd is raised in cowsheds with mainly transported feeds.

Second, if distance from a market is an important factor, it is insufficient to explain some dairy strategies, especially those oriented to dairy marketing. In the 'diversified' sub-group, the majority of farmers are isolated but continue to sell more than one-third of their milk production, at opposite to the 

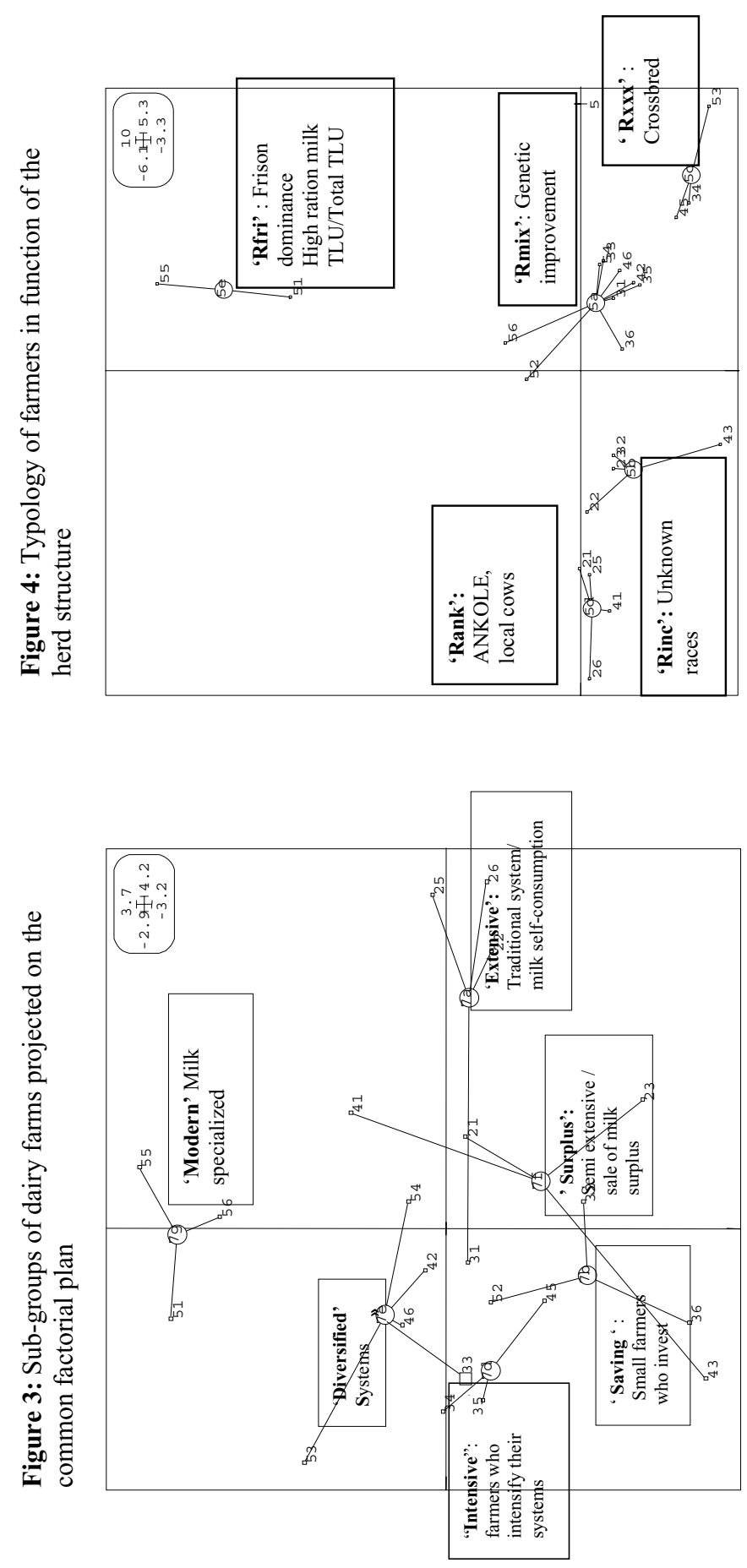
'saving' group. The main factor that differentiates these two sub-groups is family structure, especially the number of active family members. The 'diversified' sub-group is composed of more than eight members, of whom six are active, while the 'saving' sub-group consists mainly of young heads of household with young children.

Finally, the sub-group 'Genetic improvement' ('Rmixt') under the theme of herd structure, with a mixed genetic herd, is composed of farmers who originated from agricultural, agro-pastoral and pastoral areas (figure 4). In this figure, this group occupies a central position from where we can differentiate farmers who practise permanent genetic improvement ('Rfri'), farmers who invest in pastoral or breeding management with a more and more crossed herd ('Rxxx') and farmers who have difficulty in maintaining genetic improvement ('Rinc'). This last group is obliged to sell animals seasonally to face current expenditure. In this configuration, the sub-group 'Rmixt' includes farmers for whom the system fluctuates, between the different positions according to the season, and unforeseen expenditures. It is well represented in the Mbarara district.

Where the determinants of milk strategies have been identified, it is important to define the economic importance of milk in the different dairy systems that complete the profile for each of milk strategy sub-groups.

\section{Milk profitability and its contribution to farm viability}

The integration of all sources of income at the farm level permits a consideration of the viability of farming systems. It also allows researchers to study the contribution of dairy activity in maintaining or improving the economic sustainability of the farm and in improving family livelihoods. But first, it is desirable to evaluate the profitability of milk production by working out the costs, and the amount deriving from the sale of milk in the total livestock income.

For the 'diversified' or 'modern' systems, the milk production represented more than 20 percent of the total monetary entries (total receipts), while the receipts from the sale of animals represent less than ten percent of total income. In contrast, for all the others sub-groups, milk receipts are marginal compared to those from the sale of livestock (figure 5). One notes also the important role of off-farm income for the 'intensive' and 'modern' sub-groups. The off-farm income for the 'saving» group' does not exceed one million Sh., against 5.5 millions for the 'intensive' group, even if the relative part of off-farm income is similar.

The results of an analysis of the potential sources of income, estimated by the outcome of milk produced times the average producer price, can be 
Figure: 5 Structure of receipts for different milk strategy groups (in \% of total receipt)

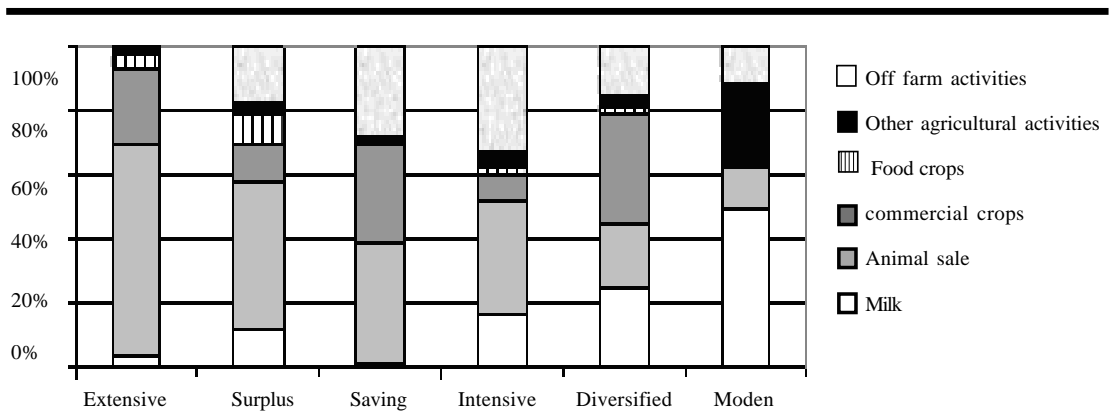

Figure: 6 Structure of gross products (in \% of total gross product)

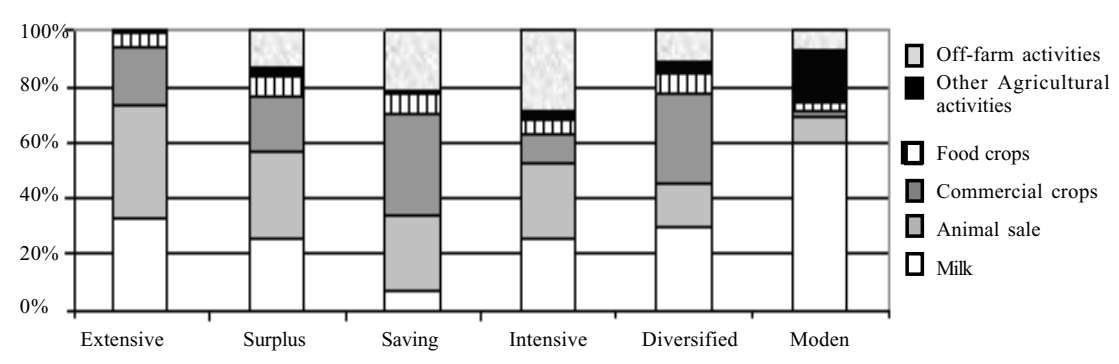

seen in the structure of the gross product given in Figure 6. It reveals the relative importance of milk for all the farmers, including the 'extensive', 'surplus' and more marginally, the 'saving' sub-groups. If social habits and the priority given to self-consumption explain a part of the none-oriented market strategies of these three sub-groups, it is not sufficient to explain the difference between potential and real receipts for the 'extensive' and 'surplus' sub-groups. In the 'saving' sub-group, despite the low level of sales, milk consumption per capita in the household (calculated at about 0.6 litre a day), does not cover the recommended protein need.

Calculation of the production costs per TLU shows the importance of wage and veterinary expenditure for the market-oriented farmers (i.e. the 'modern' and 'intensive' sub-groups). The wage expenditure exceeds 60 percent of total expenditures (Figure 7). If water transportation represents around one-quarter of the expenditure for the 'modern' sub-group, water charges (including fees for access) constitute the main costs for milk production in the pastoral areas, mainly for the 'extensive' sub-group. The struc- 
ture of the costs of milk production also shows a large gap (around double) in terms of capital investment between the 'modern' and the 'intensive' subgroups and the other sub-groups.

The total costs of milk production based on current expenditures (without integrating the depreciation of capital represented by the herds), are globally maintained below the average milk producer price, at around $180 \mathrm{Sh} . /$ litre (Survey Data 1999-2000, figure 8). This average price, however, conceals imbalances among the geographical areas. In the rainy season, the average producer price in pastoral areas (around 100 Sh./litre) does not allow the profitable commercialisation of milk production. ${ }^{4}$ Similarly, the 'saving' farms that register the main expenditure during this period (seed, fertilizer purchases, etc.) cannot make an adequate profit from milking. If depreciation of materials and buildings are included, the 'diversified' sys-

Figure 7: Total cost per TLU and per farm group (in Sh)

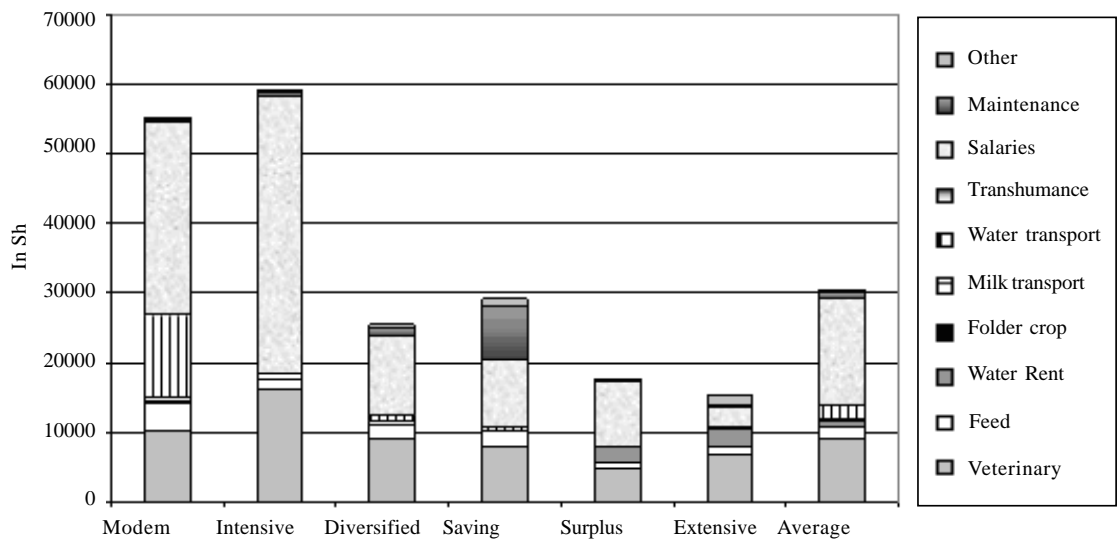

Figure 8: composition between cost of production and farm-gate price

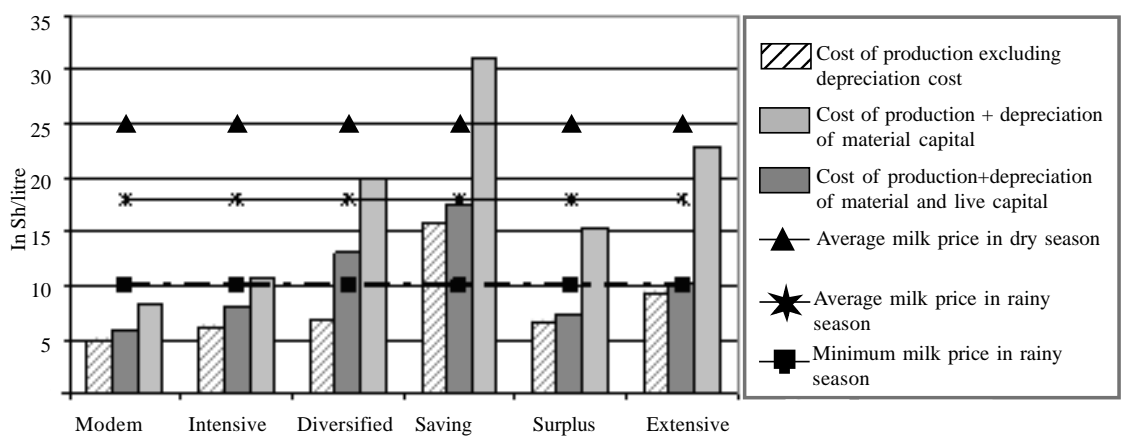


tems register a cost around 130-140 Sh./litre. With the integration of all the depreciation costs (including live capital), the margin is the most important for the 'intensive' and 'modern' farms.

The concept of viability implies the economic and social reproducibility of the farm in a sustainable way in the long-term. In this study, the concept is restricted to economic reproducibility, which can be represented by a farm's current account. This construction of a farm's current account underlies various difficulties in analysing the data, due to the strong interaction and complementarities between milk and meat activities, and also between agricultural and livestock activities (Cordonnier 1986). Most of the time, the division of the costs of livestock maintenance between milk and meat activities could be considered as merely secondary in explaining the economic advantages of milk at farm and family level. But such a distinction is essential for appreciating the significance and role of milk for farms. ${ }^{5}$

Tables 3 and 4 present the main components of the breeding and farm current accounts and the contribution from milk sales. First, and surprisingly, one can see the large part played by milk production (about 40 percent) in net profits from livestock for the sub-group of 'saving' farmers. Milk and calf production together bring in around eight percent in interest, as against the three percent from a bank account (Table 3). If the value of milk products are similar for the 'extensive' and 'diversified' farmers (in absolute and relative terms), for the 'diversified' sub-group that spends a considerable amount on constituting the dairy herd, the profit from animal products is half as much (Table 4).

These results do not reveal the overall social and economic weight of milk for the family, due to the under-estimation of self-consumption. For all the sub-groups (except for the 'saving' sub-group), milk constitutes more than 70 percent of daily protein intake (Table 5). 


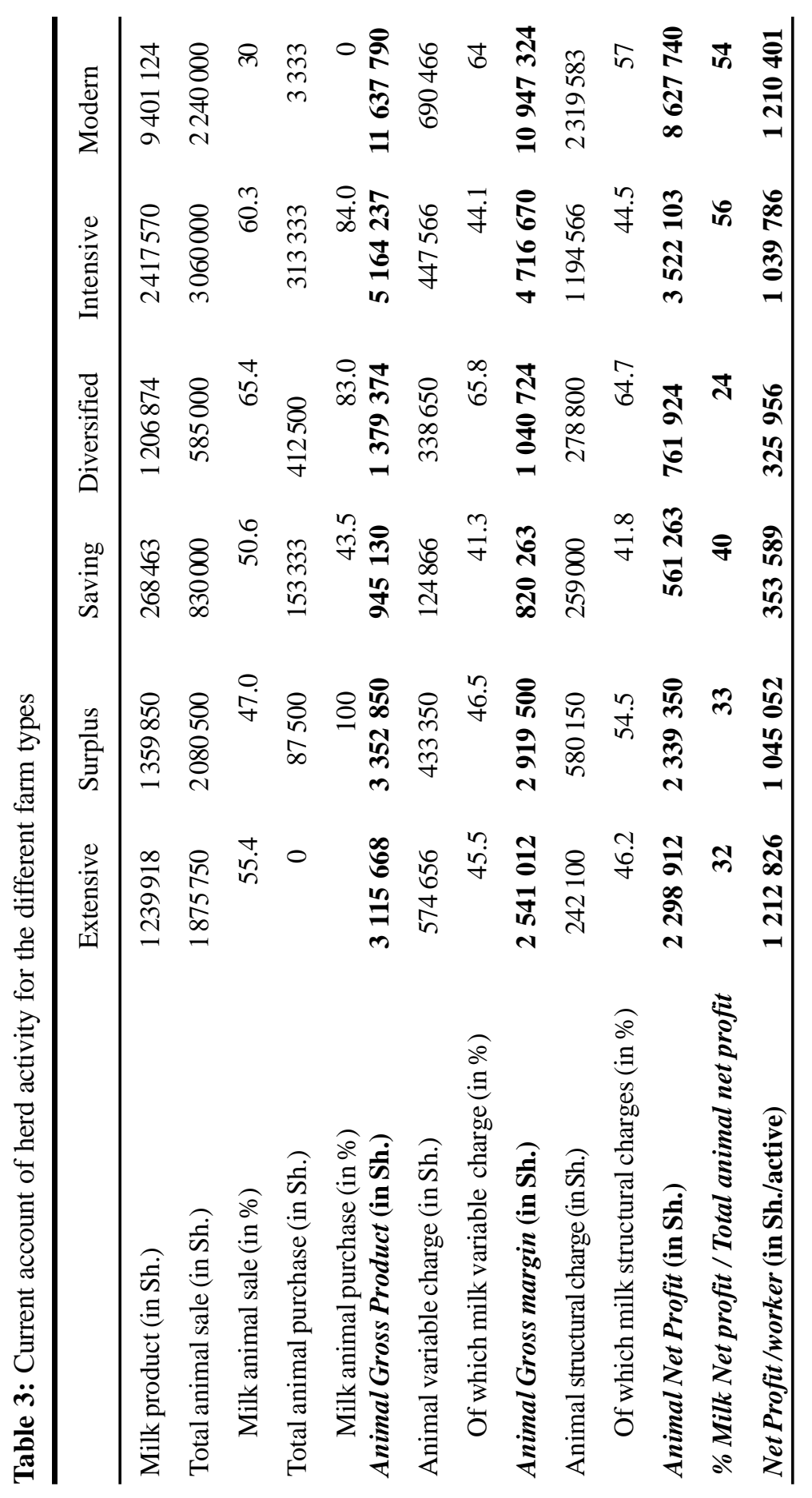




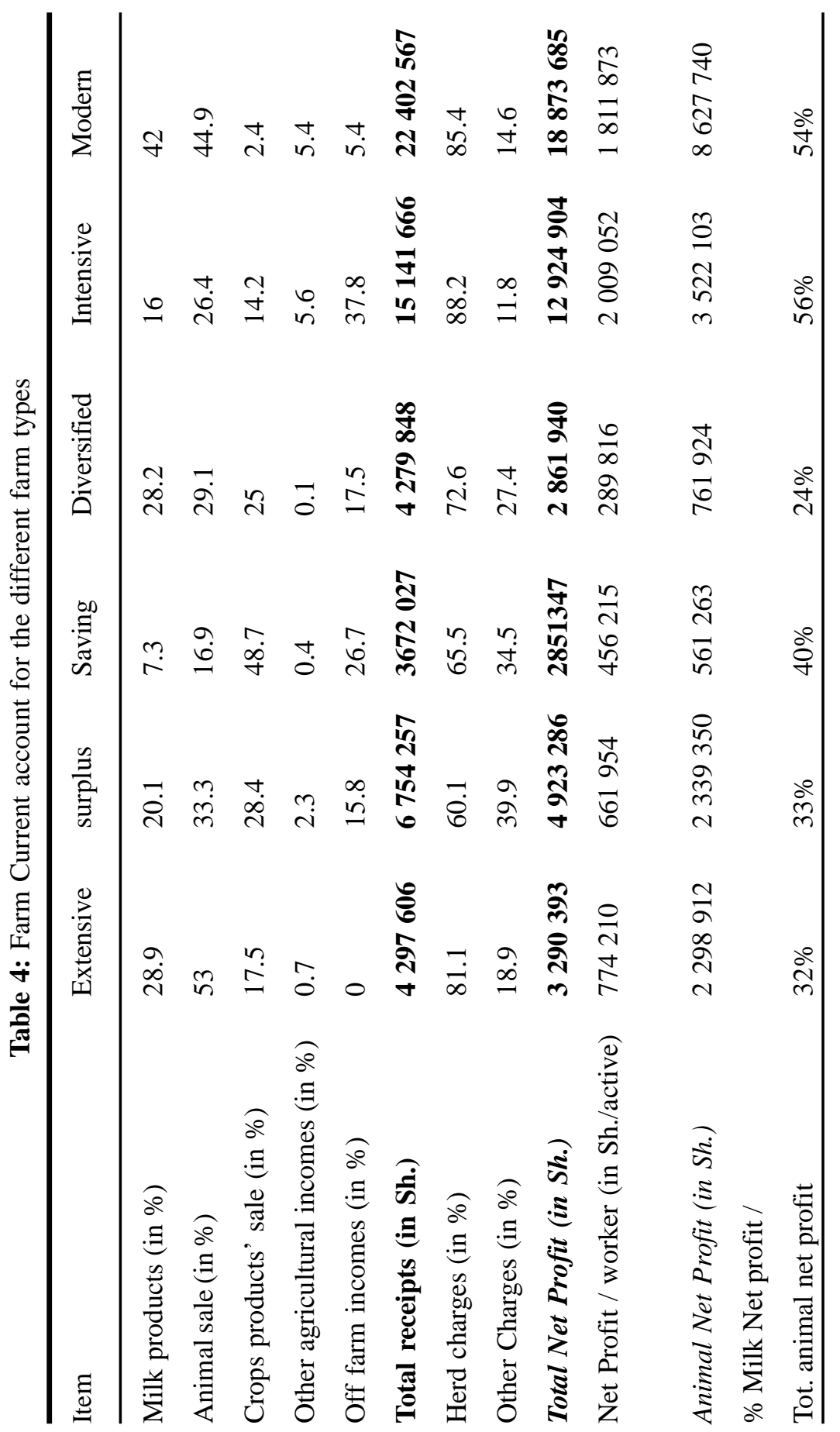


Table 5: Nutritional intake par person for each farm group

Extensive Surplus Saving Diversified Intensive Modern

\begin{tabular}{lcccccc}
\hline $\begin{array}{l}\text { Calorie content / } \\
\text { person }\end{array}$ & 2723 & 3217 & 2026 & 2420 & 2202 & 2951 \\
$\begin{array}{l}\text { Milk Calorie } \\
\text { content /person }\end{array}$ & 1462 & 1208 & 275 & 872 & 1074 & 2389 \\
$\begin{array}{l}\% \text { milk calorie/ } \\
\text { total calorie intake }\end{array}$ & $54 \%$ & $38 \%$ & $14 \%$ & $36 \%$ & $49 \%$ & $81 \%$ \\
$\begin{array}{l}\text { Protein content/ } \\
\text { person (in gr.) }\end{array}$ & 87 & 83 & 41 & 71 & 68 & 126 \\
$\begin{array}{l}\text { Milk protein content/ } \\
\text { person (in gr.) } \\
\% \text { milk protein/ }\end{array}$ & 70 & 58 & 13 & 42 & 52 & 115 \\
\begin{tabular}{l} 
total protein intake \\
\hline
\end{tabular} & $81 \%$ & $70 \%$ & $32 \%$ & $59 \%$ & $76 \%$ & $91 \%$ \\
\hline
\end{tabular}

\section{Discussion}

If the multi-factorial analysis is a descriptive and a static method, the analysis of the interactions among the different sub-groups reveals interesting profiles of dairy farming systems, that most of the time are ignored in dairy development schemas. It also allows the identification of some relationships among the different sub-groups that take place over time. This continuum with regard to the sub-groups challenges the stereotypes related to the study of livestock systems.

A significant linkage among the different milk strategy sub-groups concerns the stage of family development. At the beginning, the young farmers in the 'saving' sub-group, living alone with their wife and children, cannot undertake dairy activity because of the lack of time. At this stage, only the surplus is saved. With the enlargement of the family, the sons participate in the agricultural work. Then dairy activity constitutes a way of diversification in an area that may experience problems regarding land pressure. The importance of the farm cycle had been well demonstrated by Tchayanov (1924). This factor could be important in explaining the different dairy strategies in agricultural areas, without omitting the geographic factor. The demographic factor explains also why the 'saving' and 'diversified' systems are both in the two sub-groups of agricultural diversification ('Dmatoo', 'Dviv'). In the same way, in the pastoral community, sons are encouraged to leave the father's farm with a part of the herd as soon as they reach the 
age of marriage. Under this mode of inheritance, the average number of family members does not exceed six people in the pastoral areas, although two or three generations frequently are found on the same farm in the agricultural systems.

The combined analysis of the different sub-groups underlines the dynamic process of dairy development in agro-pastoral or agricultural systems. The first livestock investment would constitute a kind of hoarding of the agricultural surplus. Only with the enlargement of the family and the pressure of social needs, livestock can be seen as an activity of diversification, given the monetary valuation of animal products such as calves, milk, and manure. Milk is the product of agricultural diversification in the cropping system, before it becomes a way of income diversification, and then a factor of intensification in agricultural activities.

This analysis should not omit the cultural determinants that define the global environment of the farmers in terms of rules and norms. In this sense, this analysis shows the specific position of the pastoral farmers (represented by the extensive' category) who have a specific way of life, well established or rooted in the cultural tradition of the Bahimas. Nevertheless, shifts over generations can be observed. The young generation displays interest in the economic development of milking, and so join the 'saving' group. At the opposite end, non-Bahiman farmers in the groups 'Rinc' and 'Rank' always treat livestock as live saving, and prefer Ankolé cows because of their rusticity and resistance to infection. Moreover, the sale price of one Ankolé does not exceed 250,000 Sh., against the 500,000 Sh. for a Friesian cow. The costs of social needs of farmers are nearer to the Ankolé sale price, although the rate of interest (milk yield) is less. This explains the widespread maintenance of local cows in the more traditional systems.

More generally, if the cross-sectional analysis confirms the strong relationships among genetic improvement, degree of specialisation and intensification, market proximity and family expectations, the analysis also reveals rapid movement from one sub-group to another, as a result of unpredictable expenditure. In sum, it is difficult to analyse dairy strategies without taking into account the whole farming system and the family situation. The analysis shows the important relations between the social, cultural, economic and zootechnic factors that confirm the multiple and changing roles of livestock for farmers of the region (economic security, social status, risk insurance, etc.).

The construction of farms' current accounts from the analysis of the costs of milk production make it possible to demystify the social and cultural role of milk in the pastoral systems, and to identify some rational factors 
from an economic point of view that explain the various milk strategy development according to the farm types.

Firstly, the decisions with regard to breeding systems (feeding system, veterinary expenditures, etc.), depend overall on the role, or non-existence, of other agricultural activities on the farm. This explains the large investment gaps in the dairy sector between the 'modern' and 'intensive' sub-groups and the other farmers who have little access to other financing sources, in part owing to their isolation. One other main factor for dairy development is the availability of work. This factor constitutes a major problem for the pastoralists. Not only must the children leave their family very early on, but the physical distance between camp sites and the milk centres makes commercialisation time-consuming. Moreover, in these remote places, it is difficult to find occasional workers. Study of the pastoralists suggests that most of the time is spent in search of livestock grazing feed.

Secondly, the evidence from farm current accounts demonstrates the complete rationality in terms of profits around decisions on selling milk. In contrast to 'diversified' systems where farmers may profitably produce milk by selling to neighbours or the informal market where prices are 15 to 20 percent higher, pastoralists are completely dependant on milk collection centres that pay very low prices during the peak milking season (Pastel 2001). Therefore both consumers of milk and private dealers should take production costs into account if they wish to see higher productivity in the dairy sector. Low profit margins dampen investment and the renewal of herds among these farm types. Surprisingly, the 'diversified' farmers registered the lowest net profit per capita. This shows the high vulnerability of 'diversified' systems due to the role of dependant family members. In term of cash flow, pastoralists registered the lowest receipts due to the low integration with markets. We can note positive results for farmers who decided to invest in their milk production. This finding bears out the fact that when financing is available, milk activity may be a very lucrative activity.

Finally, the recomposition of farm current accounts confirms the importance of milk production for all the sub-groups of farmers, including the 'saving' group. It reinforces the point that efforts concerning milk development should not neglect small farms, as if milk production there must be low.

This analysis does not integrate the embodied capital value represented by livestock when compared to rates of inflation in insurance markets. It is also difficult to assess the other roles played by milk production, such as cementing friendships, the availability of milk on ceremonial occasions, and the immediate convertibility into cash to meet urgent expenses. Therefore these current accounts under-estimate the importance of dairy farming in 
the economic and social life of farmers in the region. But at least these preliminary results allow for an understanding of the reasons for the low involvement of some farmers in the commercialisation of milk.

\section{Conclusion}

The reconstitution of the current accounts for each farm type allows the analysis and understanding of the milk production strategies and the decisions concerning market orientation. The results confirm the limited advantages not only for pastoralists, but also for small farmers in selling milk. This situation is mainly due to the decline in the terms of exchange for these farmers (as it has been already demonstrated in pastoral areas, Thebaud 1988). The sale price does not exceed 100 Sh./litre in the rainy season, the main productive period. For the 'saving' farmers, milk activity does not represent their main objective, since they are in a phase of investment. If the milk market was more profitable, they could of course increase their welfare. For the pastoralists, milk consumption remains a family priority and it explains the importance of this product in current accounts. Nevertheless, one cannot ignore the problems of infrastructure which help explain decision-making relative to milk valuation. The low profit margin for the 'intensive' farms should alert decision-makers and development personnel to the issue of whether milk production is a priority.

\section{Notes}

1. Milk consumption was estimated at 21.5 litre per year per capita in 1999, as against 25.8 litres in Africa as a whole, and 28.1 in East Africa (FAOSTAT, 2000).

2. For example by the promotion of free milk distribution at school.

3. Matooke is a variety of banana for cooking.

4. The milk producer price is established at 180 and $300 \mathrm{Sh}$./litre, respectively in the rainy and dry seasons in the agricultural and agro-pastoral areas, compared to $100 \mathrm{Sh} / \mathrm{Litre}$ in the rainy seasons and $200 \mathrm{Sh}$./litre in the dry seasons in the pastoral area.

5. The milk product is estimated by multiplying the total collected milk with the average yearly producer price. For animal sales and purchases, the transactions with regard to calves, heifers and cows are incorporated in the milk charges, and those relative to males in other animal charges. To estimate the part of variable or structural charges in milk activity, a weighting based on the milk livestock unit on the total herd livestock unit (TLU) was used.

\section{Acknowledgements}

The present study was financed by the French Embassy in Kampala, as part of the Mbarara Milk Project. We thank particularly Mrs Baherle, Co-opera- 
tion and Cultural Action Counsellor, for her constant support for our research activities.

\section{References}

Bosman, H. G., Moll, H. A. J., Udo, H. M. J., 1997, 'Measuring and interpreting the benefits of goat keeping in tropical farm systems', Agricultural Systems, 53.

Boutonnet, J. P., 2002, 'Les conditions économiques du développement des productions animales’, Chapitre du livre, 'Zootechnie comparée’, à paraître, 32.

Chalimbaud, J., 2001, Mbarara Milk Project Workshop Proceedings, 28-30 November 2000. Rwizi Arch Hotel, Mbarara, 2001, Ministère des Affaires Etrangères/ République d'Ouganda/ Cirad-Emvt. Mars, 75p.

Coordonnier, 1986, Economie de la production laitière: Technique et Documentation, Lavoisier, INRA, 218p.

Corniaux, C., 2005, Gestion technique et gestion sociale de la production laitière: les champs du possible pour une consommation durable du lait. Cas des modes de production actuels du delta du fleuve Sénégal, Thèse en agriculture, alimentation, biologie, environnement, société - ABIES. Institut National Agronomique de Paris-Grignon (France).

Dabusti, N. and Vancauteren, D., 1999, 'Les systèmes d’élevage du district de Mbarara (Ouganda) et leur contribution à la filière laitière - Diagnostic, dynamique d'évolution et recommandations pour l'action', Mémoire de Master développement Agricole Tropical option Valorisation des productions, Mars 1999, 276p.

Escofier, B., Pagès, J., 1983, 'Méthodes pour l'analyse de plusieurs groupes de variables. Application à la caractérisation des vins rouges du Val de Loire', Revue de Statistique Appliquée, 31 (2), p 43-59.

Escofier, B., Pagès, J., 1984, 'L'analyse factorielle multiple: une méthode de comparaison de groupes de variables', in Diday, E. et al., eds., Data Analysis and Informatics III, Elsevier, North-Holland, 41-55.

Faye, B, Grelet, Y., 1990, 'Type d’élevage et profil de santé- Deux stratégies statistiques', Communication au colloque 'Agro-industrie et méthodes statistiques', Angers du 14 au 15 juin 1990. Association pour la statistique et ses utilisations, 111-125.

Faye, B., 2000, Stratégie du dépouillement des données et préparation d'une seconde phase du projet laitier de Mbarara. Rapport de mission en Ouganda du 20 au 29 avril 2000, Ministère des Affaires Etrangères/ Ambassade de France en Ouganda/ Cirad-Emvt. Mai, 17p.

Grimaud, P., Faye, B., Mugarura, L., Muhoozi, E., Bellinguez, A., 2004, ‘Identification of research activities for the dairy sector development in Uganda: systemic and participatory approaches', Uganda J. Agric. Sci., 9, 879-884.

Moll, H. A. J., Dietvorst, D. C. E., 1999, 'Cattle marketing in Zambia, 1965-1995: policies, institutions and cattle owners in the Western Province', in H. Laurens Van der Laan, Tjalling Dijkstra and Aad van Tilburg, eds., Agricultural 
Marketing in Tropical Africa: contribution for the Netherlands, Ashgate, Aldershot.

Pastel, B., 2001, Etude primaire de la filière lait dans le district de Mbarara (Ouganda), Université Paris XI Orsay / Cirad-Emv., Paris, 42.

Reardon, T., Delgado, C. and Malton, P., 1992, 'Determinants and Effects of Income Diversification amongst Farm Households in Burkina Faso', Journal of Development Studies, 39.

Starr, M. A., 1987, 'Risk, environmental variability and drought-induced impoverishment: the pastoral economy of central Niger', International African Institute, 57 (1).

Slingerland, M., 2000, Mixed farming: Scope and constraints in West African Savannah, PhD Thesis, Tropical Resource Management Papers N³4. Wageningen UR. The Netherlands.

Thébaud, B., 1988, 'Elevage et développement au Niger. Quel avenir pour les éleveurs du Sahel?’, B. I. T Publication, Genève, 138.

Tchayanov, A., 1924, L'organisation de l'économie paysanne, Traduction d'Alexis Berelowitch, Ed., Maison des Sciences de l'Homme, 342.

Van Ecbert, M., Mombeshora, B.G. and Cousins, B., 1989, 'Farmers' objectives and livestock functions', in Proceeding of the workshop on the socio-economic dimensions of livestock productions in the communal lands of Zimbabwe, 12-14 September 1988.

Vatin, F., 1996, Le lait et la raison marchande: essai de sociologie économique, Presses Universitaires de Rennes, 205. 